\title{
Entrevista com Pepetela por Jane Tutikian
}

JT: Onde se encontram a literatura e a ideologia? Na tua perspectiva, é possível separá-las? Qual o papel do escritor, na tua concepção?

P: Não me parece possível o escritor separar a sua ideologia da sua prática de escritor. É claro que se pode pôr na boca dos personagens tudo o que se queira e a literatura em parte é isso mesmo, uma discussão /confronto entre personagens de ideologias diferentes, mesmo se elas não sabem o que isso quer dizer. Mesmo os escritores mais desideologizados têm uma ideologia e um papel na sociedade.

JT: Como As Aventuras de Ngnunga, uma chamada à resistência do povo angolano ao colonialismo e outras forças de ocupação instaladas no território e a um novo homem angolano, funcionou como manual de alfabetização nas escolas do MPLA - Movimento Popular de Libertação de Angola? A criação da novela foi dirigida para essa função? Fala sobre a experiência.

P: Havia um Manual de Alfabetização para Adultos, que por acaso fui também eu que fiz. Nas escolas havia os normais livros, feitos por nós, para as crianças aprenderem a ler. No entanto, notei que não existia leitura complementar. Escrevi pois uns textos muito simples que serviriam de complemento à leitura, com a vantagem de terem a sua versão em bunda (língua da região) ao lado. Só que descobri nos primeiros textos uma estória e segui-a. Sempre com a preocupação de que a linguagem fosse o mais simples possível, para atingir o primeiro objectivo.

JT: Mayombe trata do funcionamento dos movimentos de libertação, mostrando as dificuldades enfrentadas pelos mesmos. Opta, particularmente, por descrever um grupo cujo pressuposto ideológico é a bandeira do marxismo-leninismo, fato que o vincula historicamente ao MPLA - Movimento Popular pela Libertação de Angola. Mayombe também teria tido um nascimento peculiar, como um comunicado de guerra que te cabia escrever para os membros daquele agrupamento político. Gostaria de te ouvir sobre isso.

P: Bem, não creio que se possa dizer que Mayombe tem um pressuposto marxista-leninista. Marxista, sim, mas também com alguns laivos anarquistas. Leninista não, de certeza absoluta. O leninista do grupo nem é muito bem tratado, Mundo Novo. De facto o romance nasceu como um comunicado de guerra. Vendo o comunicado, achei que a linguagem era demasiado fria e escassa para tanta emoção e tantos factos. Por isso continuei, contando a estória que surgiu nesse combate.

JT: Uma obra que me toca muito de perto é A Geração da Utopia. $O$ romance retrata três décadas movimentadas, a da luta armada, a independência, o projeto socialista, a guerra civil entre o MPLA e a UNITA, o neoliberalismo, o multipartidarismo sucedeu o regime de partido único. Um caminho da utopia à distopia de uma geração de que participaste. Em que medida a distopia te atinge? Um intelectual que acredita na resistência pelo texto tem essa possibilidade ? Pergunto isso porque nas obras que se seguem os problemas serão retomados, o processo histórico de Angola outras vezes revisitado, confirmando que o tema da construção nacional permanece, seja nas imagens multiplicadas da ruína de Luanda, alegoria central de $\mathbf{O}$ desejo de Kianda, seja na memória do escravo mudo que em A gloriosa família.

P: Continuo a considerar que as utopias são necessárias para fazer mexer o mundo, embora elas possam mudar ou adaptar-se a novas circunstâncias. Embora com avanços significativos, a problemática da identidade nacional mantém-se e temos de travar constantes combates a favor da defesa dos direitos dos angolanos, de todos os angolanos e não de uma minoria afortunada. Como se dizia nos tempos antigos, "A Luta Continua".

\section{JT: Como se dá a experiência de Pepetela de guerrilheiro a Ministro de Estado?}

P: Nunca consegui interiorizar suficientemente que era responsável por tanta coisa e de ter de lidar com a burocracia e os jogos do poder. Sempre tive saudades dos tempos da guerrilha em que as coisas eram muito mais simples e as pessoas sem ambições e mais solidárias. Foi uma experiência não muito boa

Organon, Porto Alegre, n 47, julho-dezembro, 2009, p.209 - 211 
pessoalmente, embora tenha sido útil para a literatura. Por isso recusei a partir de então todos os postos que me propuseram no aparelho de Estado.

JT: Quando o Ocidente vê a África, vê como uma aguda crise econômica; uma massiva instabilidade política, vê pela retradicionalização das sociedades africanas; e através da marginalização na cena política mundial. Por outro lado, a sociedade africana está buscando seu próprio caminho, seja na esfera jurídica e formal ou na ilegalidade e informalidade. É uma batalha contínua sobre a interface entre os diversos sistemas de valores, diferentes formas de lógica: Ocidental e Africana, urbanas $e$ rurais, homem e mulheres, jovens e idosos, progressistas e conservadores, etc Isso torna a condição africana extremamente complexa e imprevisível. Qual a relação do que se afirma com o Quase Fim do Mundo?

P: O Quase fim do Mundo é uma tentativa de chamar a atenção para perigos que o mundo de facto enfrenta. São realidades hoje, deixaram de ser ficção. Quis, por ironia, colocar a acção em África, como a última esperança da Humanidade. Já que todos nos tratam tão mal, então alguns de nós serão os únicos que sobreviverão e vão se empanturrar com todas as riquezas criadas em particular pela Europa e América. É também uma lembrança de que a sobreprodução para consumo e a vida para o simples consumo não é solução para a Humanidade.

JT: Voltando à distopia, O Planalto e a Estepe, que recupera a história de Angola dos anos 60 até os dias de hoje, termina revelando o esvaziamento das ideologias, porque esterilizadas pelas práticas. Qual o papel da literatura nesta nossa época pós-utópica?

P: Como atrás disse, não nego a necessidade de ideologias e das utopias. Serão apenas outras. Com alguns pontos comuns com algumas que são legado universal: igualdade de oportunidades de todos os humanos, liberdades fundamentais, libertação da imaginação colectiva, etc. A literatura será o que sempre foi: chamar a atenção para a forma como funcionam as pessoas e sociedades e a procura constante de algo melhor (mesmo se com alguns livros absolutamente desesperados). 